\title{
Complementary treatment to reduce blood sugar levels of type 2 diabetes mellitus patients
}

\author{
Jujuk Proboningsih ${ }^{1}$, Anita Joeliantina ${ }^{2}$, Aida Novitasari ${ }^{3}$, Dewi Purnamawati ${ }^{4}$ \\ ${ }_{1,2,3}$ Department of Nursing, Politeknik Kesehatan Kementerian Kesehatan Surabaya, Indonesia \\ ${ }^{4}$ Department of Nursing, Politeknik Kesehatan Kementerian Kesehatan Mataram, Indonesia
}

\section{Article Info \\ Article history: \\ Revised Jun 29, 2020 \\ Accepted Jul 10, 2020 \\ Keywords: \\ Bay leaves \\ Blood sugar level \\ Cinnamon \\ Complementary \\ Diabetes mellitus}

Received Mar 23, 2020

\begin{abstract}
Diabetes mellitus is a chronic disease that requires long-term management. There is a tendency in type 2 diabetes mellitus patients to use herbs as a complement to medical treatment. The purpose of this study was to analyze the use of herbs as a complement to medical treatment in reducing blood sugar levels of T2DM patients. This type of research is quasi-experimental, with 40 research subjects divided into 4 groups. Determination of research subjects by purposive sampling in accordance with established inclusion criteria. Data analysis using paired $\mathrm{T}$ test. The majority of respondents was women $(77.5 \%)$ and had no genetic history $(75 \%)$. The duration of type 2 diabetes mellitus majority was $>5$ years $72.5 \%$ ). Data on random blood sugar levels before $(\mathrm{p}=0.098)$ and after $(\mathrm{p}=0.113)$ intervention were normally distributed and homogeneous $\mathrm{p}>0.05(0.839)$. The treatment group (groups 2,3 , and 4) showed a significant decrease in random blood sugar levels as the control group (1) with a significance value $<0.05$. Giving herbs has a tendency to reduce random blood sugar levels when used as a complement to medical treatment. Bitter melon shows the effect of decreasing random blood sugar levels greater than the provision of bay leaves and cinnamon.
\end{abstract}

This is an open access article under the CC BY-SA license.

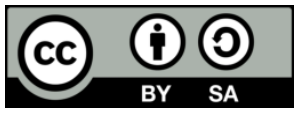

\section{Corresponding Author:}

Anita Joeliantina,

Department of Nursing,

Politeknik Kesehatan Kementerian Kesehatan Surabaya,

Jl. Mayjend. Prof. Dr. Moestopo No 8 C Surabaya, Indonesia.

Email: nita.mukhlash@gmail.com

\section{INTRODUCTION}

Diabetes mellitus (DM) is a chronic disease that occurs when the body is unable to produce enough of the hormone insulin or cannot use insulin effectively. Some of the main risk factors that can trigger tipe 2 diabetes mellitus (T2DM) include obesity, wrong diet, and lack of activity [1]. DM, in the long term can lead to macrovascular and microvascular disorders such as cardiovascular disease, bnefropati, retinopathy and neuropathy [1, 2]. The prevalence of $\mathrm{DM}$ in Indonesia is ranked seventh in the world along with China, India, the United States, Brazil, and Mexico with an estimated number of people with diabetes of 10 million in 2015 and will increase to 16.2 million in 2040. The percentage of deaths due to DM in Indonesia is the second highest after Sri Lanka [1]. T2DM patients must carry out treatments related to blood sugar control so that the body's metabolism can function properly. T2DM treatment must be carried out for a lifetime. The treatment used by T2DM patients is not only in conventional medicine, but there are patients who use complementary medicine in an effort to complement conventional treatments that have been done. Types of complementary medicine that are widely used by DM patients are herbs, supplements (vitamins and minerals), and mind body therapy [3]. The use of herbs as complementary medicine must pay attention to aspects of efficacy and safety [4]. 
The use of herbs as a treatment in Indonesia has been regulated in the Decree of the Minister of Health of the Republic of Indonesia number HK.01.07/MENKES/187/2017 regarding the Formulary of Indonesian Traditional Medicinal Herbs. Socialization on the use of herbs has now been applied to health services in Surabaya, which already has traditional treatment clinic at 20 community health centers, dr. Soetomo Surabaya, and Surabaya UNAIR Hospital. Nurses as part of health workers are authorized to perform complementary and alternative nursing management in carrying out their duties as providers of Nursing Care in the field of public health efforts [5]. Indonesia is a country that is very rich in natural biological resources because Indonesia's topography and tropical climate supports the growth of a variety of plants. This is a potential that must be exploited and preserved for the purpose of human welfare. Herbs that are often used by DM patients are syzygiumpolianthum, momordicacharantia (bitter gourd), cinnamomum, trigonellafoenum-graecum (fenugreek), gymnemasylvester, cocciniagrandis (ivy gourd), ginger and allium sativum (garlic) [3, 6-8]. T2DM patients who have a tendency to use herbs to regulate blood sugar levels should receive support to continue self-care regularly. Family support influence the behavior of the use of herbs as a complementary treatment based diabetes self-management need to be developed to achieve the regulation of blood sugar levels of T2DM patients [9]. The purpose of this study was to analyze the use of herbs as acomplementary treatment for reducing blood sugar levels in patiens with T2DM. Herbs was used in this study were bay leaves, cinnamon bark, and bitter melon.

\section{RESEARCH METHOD}

This study was quasi-experimental type of research using pre-post test group design. The population in this study were T2DM patients who used or had experience using herbs besides medical treatment, who visited the Community Health Center in Surabaya (Tambak Rejo, Tanah Kali Kedinding, Pucang Sewu). The study was conducted in May-August 2018. The sample in this study was T2DM patients who were using herbs $>2$ months or had experience using herbs $>2$ months besides medical treatment visiting a Community Health Center in Surabaya. The sample size in this study was 40 respondents who were selected using purposive sampling technique. Criteria for inclusion of respondents were aged 30-60 years, suffering from DM >1 year, patients only received oral hypoglycemic treatment, did not have concomitant diseases, and were willing to become respondents by signing the consent form as a respondent. Confounding variables were not strictly controlled; the control was only by determining the inclusion criteria so that respondents who did not meet these criteria will be excluded.

T2DM patients as respondents were divided into 4 groups: Group 1 (control group), namely the group that only consumed oral hypoglycemic drugs, group 2, which was the group that consumed oral hypoglycemic drugs and added bay leaves as much as 7 sheets of medium size, group 3 , namely the group that consumed drugs oral hypoglycemic and cinnamon added with a size of 1 finger segment, and groups of 4 groups who took oral hypoglycemic drugs and added 200 grams of bitter melon. The number of respondents in each group is 10 people. Herbs (bay leaves, cinnamon, and bitter melon) which are used as a complement to medical treatment are provided in the form of decoction. Selected respondents have received approval from doctors at community health centers (Tanah Kali Kedinding, Tambak Rejo, and Pacar Keling) in Surabaya as research sites. Patients who are already willing to be respondents were given an explanation of the Module for Using Herbs as a Medical Treatment Complement in type 2 diabetes mellitus patients and signing the consent form. Patients carry out DM management in accordance with the explanation given in accordance with the module for 7 days. On the 8th day a final evaluation was carried out by checking random blood sugar levels using a glucotest tool. Analysis of the data used was paired t test to determine changes in random blood sugar levels before and after herbal administration from each group.

\section{RESULTS AND DISCUSSION}

T2DM patients who were the subjects of this study were those who met the inclusion criteria that had been set. The results of this study illustrate the characteristics of T2DM patients, random blood sugar levels, and the results of different random blood sugar levels before and after herbal administration.

\subsection{Description of the characteristics of T2DM patients}

Characteristics of T2DM patients can be seen in Table 1. The majority of respondents is women $(77.5 \%)$ and has no genetic history (75\%). The duration of T2DM majority was $>5$ years $72.5 \%$ ).

\subsection{Description of blood sugar levels}

Table 2 shows the minimum, maximum, and average blood sugar levels. Data on average blood sugar levels have been tested for data normality using the Kolmogorov Smirnov one sample test. The significance of the normality test results is said to be normal if the value of $\mathrm{p}>0.05$. Data normality test results on random blood sugar levels before $(\mathrm{p}=0.098)$ and after $(0.113)$ intervention were normally 
distributed. Homogeneity test data is performed using the Levene Test. Significance in the glucose level data was $p>0.05$ (0.839), so the data was homogeneous. Data of random blood sugar levels before and after are normally distributed and homogeneous, and the paired test is then performed.

Table 1. Characteristics of T2DM patients

\begin{tabular}{lccc}
\hline \multirow{2}{*}{ Characteristics } & & \multicolumn{2}{c}{ Frequency $(\mathrm{n}=40)$} \\
& & $\mathrm{n}$ & $\%$ \\
\hline \multirow{2}{*}{ Age } & $30-40$ & 3 & 7,5 \\
& $40-50$ & 20 & 50 \\
\multirow{3}{*}{ Gender } & $50-60$ & 17 & 42,5 \\
& Male & 9 & 22,5 \\
Long suffered from DM & Female & 31 & 77,5 \\
\multirow{3}{*}{ Hereditary History } & $1-5$ years & 11 & 27,5 \\
& 6-10 years & 29 & 72,5 \\
& Yes & 10 & 25 \\
& No & 30 & 75 \\
\hline
\end{tabular}

Table 2. Values of blood sugar levels

\begin{tabular}{lccccc}
\hline \multicolumn{1}{c}{ Group } & $\mathrm{N}$ & Min & Max & Mean & Std. Dev \\
\hline Group 1 before & \multirow{2}{*}{10} & 107 & 438 & 281 & 116 \\
Group 1 after & \multirow{2}{*}{100} & 405 & 244 & 105 \\
Group 2 before & \multirow{2}{*}{10} & 166 & 470 & 308 & 108 \\
Group 2 after & & 111 & 377 & 230 & 91 \\
Group 3 before & \multirow{2}{*}{10} & 194 & 501 & 332 & 98 \\
Group 3 after & & 135 & 475 & 281 & 94 \\
Group 4 before & \multirow{2}{*}{10} & 167 & 548 & 282 & 134 \\
Group 4 after & & 107 & 377 & 205 & 89 \\
\hline
\end{tabular}

\subsection{Test different mean random blood sugar levels}

Table 3 explains the values of random blood sugar levels before and after herbal administration as a complement to medical treatment in T2DM patients. Herbs used are bay leaves, cinnamon bark, and bitter melon. The mean value of random blood sugar levels after herbal administration has decreased compared to before herbal administration. The mean value of random blood sugar changes before and after herbal administration in the treatment group given bay leaves was greater than that given cinnamon or bitter melon that is equal to $78 \mathrm{~m} / \mathrm{dl}$.

Table 3. Mean values and intersections of random blood sugar levels

\begin{tabular}{|c|c|c|c|c|c|}
\hline \multirow{2}{*}{\multicolumn{2}{|c|}{ Group }} & \multicolumn{3}{|c|}{ Random Blood Sugar Levels } & \multirow[t]{2}{*}{ Sig. } \\
\hline & & Before & After & Difference in value & \\
\hline \multirow{2}{*}{ Group 1} & $(\bar{X})$ & 281 & 244 & 37 & \multirow{2}{*}{0.006} \\
\hline & $\pm \mathrm{SD}$ & 116 & 105 & 11 & \\
\hline \multirow{2}{*}{ Group 2} & $(\overline{\boldsymbol{X}})$ & 308 & 230 & 78 & \multirow{2}{*}{0.006} \\
\hline & $\pm \mathrm{SD}$ & 108 & 91 & 17 & \\
\hline \multirow{2}{*}{ Group 3} & $(\bar{X})$ & 332 & 281 & 51 & \multirow{2}{*}{0.011} \\
\hline & $\pm \mathrm{SD}$ & 98 & 94 & 4 & \\
\hline \multirow{2}{*}{ Group 4} & $(\bar{X})$ & 282 & 205 & 77 & \multirow{2}{*}{0.004} \\
\hline & $\pm \mathrm{SD}$ & 134 & 89 & 45 & \\
\hline
\end{tabular}

The significance of changes in random blood sugar levels before and after herbal administration interventions will be tested using paired $t$ tests. The results of the significance of blood sugar levels before and after herbal administration can be seen in Table 2. So the use of bay leaf herbs, cinnamon bark, and bitter melon as a complementary treatment accompanied by appropriate self-care behavior in T2DM patients, can reduce patients' blood sugar levels T2DM. The use of bitter melon as a complement to medical treatment can reduce higher than the use of bay leaves and cinnamon. The results obtained at this study is a significant decrease in random blood sugar levels of patients before and after herbal intervention as a complementary treatment. Different test results showed that there were significant differences in random blood sugar levels in the provision of bay leaves and cinnamon bark, and bitter melon as a complementary medical treatment in reducing random blood sugar levels. T2DM patients use a variety of herbs that can reduce their blood sugar levels. Herbs used are bayleaf, paniculata, altilis leaves, a combination of bayleaf and paniculata, cinnamon, pace, ruellia tuberosa plant, and vemonia amygdalina $[10,11]$. Natural ingredients that have been reported to increase insulin activity in vitro in reducing blood sugar levels are cinnamon bark, cloves, bay leaves, and turmeric. Chemical compounds present in bay leaves are tannin, flavonoids, essential oils, citral, eugenol, sesquiterpenes, triterpenoids, steroids, lactones, saponins and carbohydrates. In addition, bay leaves also contain several vitamins, including vitamin $\mathrm{C}$, vitamin $\mathrm{A}$, 
thiamine, riboflavin, niacin, vitamin B6, vitamin B12 and folate. Minerals such as selenium are found in bay leaves. It is known that compounds in bay leaves such as eugenol, tannin and flavonoids can be used to reduce blood sugar levels [12]. The active compounds in cinnamon bark that have the most active role in reducing blood sugar levels are sinnamic acid, sinnamaldehid, polyphenols and flavonoids [13].

Flavonoids have an inhibitory effect on the alpha gukosidase enzyme through hydroxylation bonds and substitution in the $\beta$ ring. This inhibitory principle is related to acarbose which has been used as a cure for DM, namely by producing hydrolysis, disaccharide and absorption loans which are combined by using sucrose savings into mining and fructose $[12,14]$. Flavonoid glycoside compounds in bay leaves have a function as a catcher of hydroxyl radicals so as to prevent diabetogenic action [15]. Eugenol contained in bay leaves is a compound that has antioxidant activity similar to $\alpha$-tochopherol which is able to protect cell membranes from the lipid peroxidation process. These antioxidant compounds possessed by bay leaves can help repair pancreatic $\beta$ cell damage and provide protection to healthy cells, so they can normalize insulin production. This improvement in insulin production will ultimately make blood sugar levels return to normal [12].

Sinnamic acid contained in cinnamon bark acts as a trigger for insulin and increases the expression of GLUT 4 as an insulin transporter in muscle tissue. Sinnamic acid is also reported to be able to inhibit the enzyme HMG-CoA reductase in the liver and reduce lipid peroxidation in the liver [13]. The results of Cinnamomumburmanii bark extract contain the main antioxidant compounds, namely polyphenols (tannins, flavonoids) and phenol essential oils. The Cinnamomumburmannii Blume plant that is commonly found in Indonesia has antidiabetic activity. Extracts from Cinnamonum stem bark or leaves have potential that can be used to treat type 2 diabetes. The antidiabetic activity shown varies, including a decrease in blood sugar levels, inhibition of the activity of the $\alpha$ glucosidase enzyme and control of glucose metabolism in nondiabetic adults during the postprandial period [16, 17]. Antidiabetic mechanisms of cinnamon are thought to affect several insulin signaling pathways, including in insulin receptors, glucose 4 transporters (GLUT 4), glucose-1 transporters (GLUT 1), proliferator peroxide activator receptors (PPAR) [18].

Bitter melon extract contains complex compounds including insulinmimetics, vitamins, minerals, and antioxidants. Insulinmimetics include carantine, polypeptide-p and visin. Vitamins found in bitter melon include vitamins $\mathrm{C}, \mathrm{E}, \mathrm{B} 1, \mathrm{~B} 2, \mathrm{~B} 3$ and $\mathrm{B} 9$ (folate). Bitter melons also contain minerals, namely potassium, calcium, zinc, magnesium, phosphorus, and iron. As well as antioxidants in bitter melon fruit, namely phenols, flavonoids, isoflavones, terpenes, anthraquinones, and glucosinolates [19]. Bitter melon extract is known to have several mechanisms in reducing blood glucose, namely stimulation of glucose use in peripheral tissues and skeletal muscle, inhibition of glucose uptake in the intestine, inhibition of adipose differentiation, suppression of gluconeogenesis enzymes, and stimulation of HMP pathway enzymes [19-21]. The mechanism of glucose reduction by bitter melon extract by increasing glucose use in skeletal muscle and peripheral tissues, inhibition of glucose absorption in the small intestine, inhibition of adipose differentiation, suppression of major enzymes in gluconeogenesis, stimulation of major enzymes in the HMP pathway, and maintaining beta cell islets with their function. mechanism of increasing glucose levels in the blood that is by gluconeogenesis. Bitter melon can inhibit the increase in glucose by inhibiting enzymes in gluconeogenesis. The enzymes that are inhibited by bitter melon are glucose-6-phosphatase and fructose -1.6 bisphosphatase. While the enzymes that increase are glucose-6-phosphatdehydrogenase [20, 22, 23]. The use of herbs in reducing blood sugar levels cannot be achieved optimally if it is not balanced with the implementation of self-care on a regular basis. Eating arrangements must be done, because it can maintain body weight, reduce levels of fat in the blood, and make the pancreas can perform its functions more regularly. The health status of diabetes patients shows the efficacy of the CAM use was evaluated on satisfaction with CAM and the patient's health status. Satisfaction of T2DM patiens in using the CAM includes the efficacy and safety of CAM selected [24]. Some natural health products have shown a lowering of A1C by $\geq 0.5 \%$ intrials lasting at least 3 months in adults with type 2 diabetes, but most aresingle, small trials that require further large-scale evaluations before theycan be recommended for widespread use in diabetes [25].

\section{CONCLUSION}

The use of herbs by T2DM patients has a tendency to reduce random blood sugar levels when used as a complement to medical treatment. Bitter melon shows the effect of decreasing random blood sugar levels greater than the provision of bay leaves and cinnamon. The use of herbs should be followed by self-care behavior appropriately and regularly.

\section{ACKNOWLEDGEMENTS}

The authors thank the adults with type 2 diabetes mellitus in Surabaya City, East Java, Indonesia for their participation. Thank you to the director of the Health Polytechnic of the Ministry of Health, Surabaya Indonesia for funding support for this research 


\section{REFERENCES}

[1] International Diabetes Federation. "Diabetes Atlas", $7^{\text {th }}$ ed., pp. 17, 2015

[2] Li, R., Zhang, P., Barker L., Chowdhury, F., et al., "Standards of Medical Care in Diabetes-2013," Diabetes Care, vol. 36, Supl. 1, pp. S11-66, 2013.

[3] Birdee, G. S., Yeh, G., "Complementary and Alternative Medicine Therapies for Diabetes: A Clinical Review," Clinical Diabetes, vol. 28, no. 4, pp. 147-155, 2010.

[4] Wachtel-Galor, S., Benzie, I., "Herbal Medicine: An Introduction to Its History, Usage, Regulation, Current Trends, and Research Needs," In: Herbal Medicine: Biomolecular and Clinical Aspects, $2^{\text {nd }}$ ed, pp. 1-11, 2011.

[5] Republic of Indonesia, Law No. 38 of 2014 Concerning Nursing 17 October 2014. State Gazette of the Republic of Indonesia. No. 307. Jakarta, 2014.

[6] Hashempur, M. H., et al., "Complementary and Alternative Medicine Use in Iranian Patients with Diabetes Mellitus," Journal of Integrative Medicine, vol. 13, no. 5, pp. 319-325, 2015.

[7] Medagama, A. B., et al., "Use of Complementary and Alternative Medicines (CAMs) among Type 2 Diabetes Patients in Sri Lanka: A cross sectional survey," BMC Complementary and Alternative Medicie vol. 14, no. 374, pp. 1-5, 2014.

[8] Ching, S. M., et al., "Complementary Alternative Medicine Use among Patients with Type 2 Diabetes Mellitus in the Primary Care Setting: a Cross-Sectional Study in Malaysia," BMC Complementary and Alternative Medicie, vol. 13, no. 148, pp. 1-7, 2013.

[9] Joeliantina, A., et al., "Family Support for Diabetes Self-care Behavior in T2DM Patients who Use Herbs as a Complementary Treatment," Medico-Legal Update, vol. 19, no. 1, pp. 238-243. 2019.

[10] Joeliantina, A., et al., "Responses of Diabetes Mellitus Patients who Used Complementary Medicine," International Journal of Public Health Science (IJPHS), vol. 5, no. 4, pp. 367-374, 2016.

[11] Emalia, O., et al., "Influence of Antidiabetic Herbal Medicine to a Decrease Blood Glucose Levels of Diabetes Mellitus Patients at The 'Hortus Medicus' Scientification of Jamu Clinic Tawangmangu, Karanganyar," Indonesian Journal of Clinical Pharmacy, vol. 5, no. 1, pp. 19-25, 2016.

[12] Taufiqurrohman, "Indonesian Bay Leaves as Antidiabetic for Type 2 Diabetes Mellitus," Medical Journal of Lampung University, vol. 4, no. 3, pp. 101-108, 2015.

[13] Lakshmi, B. S., et al., "Cinnamic Acid, from The Bark of Cinnamomum Cassia, Regulates Glucose Transport via Activation of GLUT4 on L6 Myotubes in a Phosphatidylinositol 3-Kinase-Independent Manner," Journal of Diabetes, vol. 1, no. 2, pp. 99-106, 2009.

[14] Lelono R. A. A., Tachibana S., "Preliminary Studies of Indonesian Eugenia Polyantha Leaf Extracts as Inhibitors of Key Enzymes for Type 2 Diabetes," Journal of Medical Sciences (Faisalabad), vol. 13, no. 2, pp. 103-110, 2013.

[15] Parisa, N., "Effects of Bay Leaf Extract on Blood Glucose Levels," JK Unila, 2016.

[16] Ervina, M., Nawu, Y. E., and Esar, S. Y., "Comparison of in Vitro Antioxidant Activity of Infusion, Extract and Fractions of Indonesian Cinnamon (Cinnamomum burmannii) Bark," International Food Research Journal, vol. 23, no. 3, pp. 1346-1350, 2016.

[17] Emilda, E., "Effects of Bioactive Compounds from Cinnamomum Burmanii Nees Ex. Bl on Diabetes Mellitus: Literature Review," Jurnal Fitofarmaka Indonesia, vol. 5, no. 1, pp. 246-252, 2018.

[18] Medagama, A. B., "The Glycaemic Outcomes of Cinnamon, a Review of the Experimental Evidence and Clinical Trials," Nutrition Journal, vol. 14, no. 108, pp. 1-12, 2015.

[19] Joseph, B., Jini, D., "Antidiabetic Effects of Momordica charantia (Bitter Melon) and Its Medicinal Potency," Asian Pacific Journal of Tropical Disease, vol. 3, no. 2, pp. 93-102, 2013.

[20] Bahagia, W., et al., "Potency of Bitter Mellon (Momordhica charantia Fruit as Lowering Blood Glucose Levels: Benefits behind Bitter Flavor," Majority, vol. 7, no. 10, pp. 177-181, 2018.

[21] Parawansah, et al., "Anti-diabetic Test of Bitter Melon Extract (Momordica charantia L.) On Decreased Blood Glucose Levels in Streptozotocin-Induced Mice," Jurnal Medula, vol. 5, no. 1, pp. 410-415, 2017.

[22] Shibib, B. A., et al., "Hypoglycaemic Activity of Coccinia indica and Momordica charantia in Diabetic Rats: Depression of The Hepatic Gluconeogenic Enzymes Glucose-6-phosphatase and Fructose-1,6-bisphosphatase and Elevation of Both Liver and Red-cell Shunt Enzyme Glucose-6-phosp," The Biochemical Journal, vol. 292, no. 1, pp. 267-270, 1993.

[23] Jia, S., et al., "Recent Advances in Momordica Charantia: Functional Components and Biological Activities," International Journal of Molecular Sciences, vol. 28, no. 12, pp. 1-25, 2017.

[24] Joeliantina A., et al., "A Literature Review of Complementary and Alternative Medicine Used among Diabetes Mellitus Patients," International Journal of Public Health Science (IJPHS), vol. 8, no. 2, pp. 277-286, 2019.

[25] L. D., Grossman, et al., "Complementary and Alternative Medicine for Diabetes," Canadian Journal of Diabetes, vol. 42, pp. S154-S161. 2018. 